\title{
1 An Alkaline Spring System within the Del Puerto Ophiolite (California USA): A \\ 2 Mars Analog Site
}

5 J.G. Blank $\left(1,2^{*}\right)$, S. Green $\left(2^{\dagger}\right)$, D. Blake (2), J.W. Valley (3), N.T. Kita (3), A. Treiman 6 (4), P.F. Dobson (5)

8 (1) SETI Institute, Mountain View CA 94043 USA; (2) NASA/Ames Research Center, 9 Moffett Field CA 94035 USA; (3) Department of Geology and Geophysics, University of

10 Wisconsin, Madison, WI 53706 USA; (4) Lunar and Planetary Institute, Houston, TX 1177058 USA; (5) Earth Sciences Division, Lawrence Berkeley National Laboratory, 12 Berkeley CA 94720 USA

14 Key words: Mars analog, dolomite, alkaline springs, biosignature

\section{Abstract}

17 Mars appears to have experienced little compositional differentiation of primitive

18 lithosphere, and thus much of the surface of Mars is covered by mafic lavas. On Earth,

19 mafic and ultramafic rocks present in ophiolites, oceanic crust and upper mantle that have

20 been obducted onto land, are therefore good analogs for Mars. The characteristic

21 mineralogy, aqueous geochemistry, and microbial communities of cold-water alkaline

22 springs associated with these mafic and ultramafic rocks represent a particularly

* Corresponding author. Tel. 1650810 0232. E-mail address: jblank@seti.org

${ }^{\dagger}$ Now at Department of Oceanography, Florida State University, Tallahassee, FL 32306 USA 
23 compelling analog for potential life-bearing systems. Serpentinization, the reaction of

24 water with mafic minerals such as olivine and pyroxene, yields fluids with unusual

25 chemistry ( $\mathrm{Mg}-\mathrm{OH}$ and $\mathrm{Ca}-\mathrm{OH}$ waters with $\mathrm{pH}$ values up to $\sim 12$ ), as well as heat and

26 hydrogen gas that can sustain subsurface, chemosynthetic ecosystems. The recent

27 observation of seeps from pole-facing crater and canyon walls in the higher Martian

28 latitudes supports the hypothesis that even present conditions might allow for a rock-

29 hosted chemosynthetic biosphere in near-surface regions of the Martian crust. The

30 generation of methane within a zone of active serpentinization, through either abiogenic

31 or biogenic processes, could account for the presence of methane detected in the Martian

32 atmosphere. For all of these reasons, studies of terrestrial alkaline springs associated

33 with mafic and ultramafic rocks are particularly timely. This study focuses on the

34 alkaline Adobe Springs, emanating from mafic and ultramafic rocks of the California

35 Coast Range, where a community of novel bacteria is associated with the precipitation of

36 Mg-Ca carbonate cements. The carbonates may serve as a biosignature that could be

37 used in the search for evidence of life on Mars.

\section{$39 \quad$ 1. Introduction}

41 A critical challenge facing the search for life in the solar system is the identification of

42 unambiguous evidence of life (cf., Beaty et al., 2005). The presence of microbial life on

43 Earth or an extraterrestrial planet does not ensure our ability to detect it. Evidence of life

44 must be distinctive from a landscape created by abiotic processes (cf., Dietrich and

45 Perron, 2006). The presence of water is deemed to be one of the key requirements for 
46 identifying an environment capable of hosting life on Mars (e.g., Knoll and Grotzinger,

47 2006). The goal of this study is to identify possible biosignatures from a Martian analog

48 environment, namely, alkaline springs associated with ophiolites, sections of ocean crust

49 and upper mantle that have been obducted onto continental crust, experiencing varying

50 degrees of hydrothermal alteration in the process.

52 Serpentinization, the reaction of water with olivine- and pyroxene-rich rocks common in

53 mafic and ultramafic rocks to form serpentine, also produces heat and hydrogen gas that

54 can sustain subsurface, chemosynthetic ecosystems, and also results in the formation of

55 Mg-rich alkaline fluids. These fluids, when mixed with seawater (as seen at Lost City;

56 Kelley et al., 2005) or emanating as surface waters (e.g., as described comprehensively

57 by Pentecost, 2005) can produce substantial volumes of secondary carbonate deposits

58 (e.g., Surour and Arafa, 1997). Alkaline springs associated with mafic and ultramafic

59 rocks are model settings in which to identify possible mechanisms of biosignature

60 formation because these compositions of rocks have persisted throughout all of the

61 Earth's history. More importantly, low-temperature aqueous alteration processes (such as

62 serpentinization) associated with mafic and ultramafic rocks on Earth are thought to be

63 geologically similar to those occurring on Mars (e.g., Boston et al., 1992; Ming et al.,

64 2006; Wyatt and McSween, 2006).

65

661.1 Mafic and ultramafic rocks as analog settings for early Earth, early Mars, and $67 \quad$ other rocky planets 
69 Interaction between reducing rocks (e.g., unweathered basalts and ultramafic rocks) and

70 water results in an exothermic reaction that also produces hydrogen and methane, both

71 potential energy sources for chemosynthetic microorganisms (Kelley et al., 2005; Sleep

72 et al., 2004). Unfortunately, more detailed characterization of these systems is often

73 limited by their relative inaccessibility - whether in the deep-sea hydrothermal

74 environments or deep within the continental crust. More accessible systems are offered

75 by ophiolite terranes, sections of oceanic crust and upper mantle that have been obducted

76 onto land and which include both basaltic and ultramafic rocks. Similar rock types are

77 (and were) abundant on planetary bodies - the crusts of differentiated bodies (such as

78 Earth, Mars, Venus, and 4 Vesta) contain basaltic and ultramafic rock, and most

79 undifferentiated bodies (chondritic asteroids) are composed entirely of ultramafic rocks.

81 The serpentinization of mafic and ultramafic rocks can provide reduced substrates

82 suitable for microbial growth, and can yield secondary phases that may act as a

83 preservation medium for microbial organisms and their biosignatures (Fisk and

84 Giovannoni, 1999). The liberation of $\mathrm{H}_{2}$ in these systems by mineral-water interaction

85 may be partially self-sustaining, given that a volume increase of as much as $60 \%$ during

86 serpentinization (Shervais et al., 2005a) creates the potential for mechanical fracturing,

87 which continually exposes new, unreacted mineral surfaces to water and, potentially,

88 organisms. Such an environment can persist for long periods, as the heat generated by

89 serpentinization has been shown to be sufficient to drive hydrothermal circulation of

90 highly reducing fluids over tens of thousands of years (Früh-Green et al., 2003). 
92 On the early Earth, mafic and ultramafic rocks occurring in oceanic-type crust were

93 abundant, but little of this ancient crust remains today in a form that has not been highly

94 altered. Where present, obducted mafic and ultramafic rocks associated with ophiolite

95 terranes may represent an excellent terrestrial analog to Martian geology, since identified

96 Martian meteorites are either basalts or ultramafic rocks (e.g., Singer and McSween,

97 1993), and recent mapping of the Mars surface has revealed the dominance of mafic

98 rocks (Christensen et al., 2005). Any aqueous alteration of the Martian surface would

99 thus involve interaction with mafic and ultramafic rocks. This hypothesis is supported by

100 evidence from Martian meteorites, in which the predominant style of aqueous alteration

101 is that of olivine to phyllosilicates (Newsom et al., 2001; Treiman and Goodrich, 2002;

102 Leshin and Vicenzi, 2006), and to carbonates (Treiman and Romanek, 1998; Leshin et

103 al., 1998; Eiler et al., 2002), analogous to serpentinization of ophiolites. Additionally, the

104 recent discovery of hematite at the Meridiani Planum on Mars (Squyres et al., 2004a, b)

105 and quartz veinlets in eucrite meteorites (Treiman et al., 2004) and in a Mars meteorite

106 (Valley et al., 1997) are indicative of a history of aqueous alteration and activity on the

107 surface of Mars and other planetary bodies (e.g., asteroids). The generation of methane

108 within a zone of active serpentinization on Mars (through either abiogenic or biogenic

109 processes) could account for the presence of methane detected in the Martian atmosphere

110 (Formisano et al., 2004). Although currently Earth is the only planet we know of where

111 liquid water is stable at the surface, models based on recent satellite and Mars rover

112 observations of aeolian and fluvial sediments (e.g., Baker, 2006; Andrews-Hanna et al.,

113 2007) conclude that water was once present at the Martian surface, implying that both

114 surface and subsurface environments could have undergone serpentinization reactions, 
115 and potentially supported life. While carbonates have not been identified on the surface

116 of Mars to date (although their presence is suggested by early returns from the Phoenix

117 Mars Lander), and recent detection of jarosite and other sulfate minerals hints that

118 portions of the surface of Mars are acidic today (Squyres and Knoll, 2005; Squyres et al.,

119 2006), carbonates may have been present at the surface of Mars early in this planet's

120 history (e.g., Treiman, 1998: Treiman and Romanek, 1998; Eiler et al., 2002), when more

121 widespread fluvial activity occurred (e.g., McEwan et al., 2007).

123 The continental borderland of California contains numerous ophiolite blocks of similar

124 age, ranging from $\sim 172-164$ Ma (Shervais et al., 2005b). Groundwaters circulating

125 within a number of ophiolite bodies found in the California Coast Range have reacted,

126 and continue to react, with the ultramafic rocks to yield cold springs with unusual

127 chemistry ( $\mathrm{Mg}-\mathrm{OH}$ and $\mathrm{Ca}-\mathrm{OH}$ waters with $\mathrm{pH}$ values up to $\sim 12$; e.g., Barnes and $\mathrm{O}$ 'Neil,

128 1971). Schulte et al. (2006) describe the petrology and mineral chemistry of the

129 ophiolite-hosted Complexion Spring ( $\mathrm{pH} \sim 12)$, and have proposed criteria for identifying

130 serpentinized mafic rocks on Mars that may sustain chemosynthetic life. While such

131 waters can support a significant microbial load (Sleep et al., 2004), the springs and their

132 associated carbonate cements have not been studied in the context of biosignature

133 formation. The characteristic mineralogy and aqueous geochemistry of ophiolite-hosted

134 alkaline springs suggest that they may represent a particularly compelling analog for

135 potential life-bearing systems on early or modern Mars, and on the early Earth. For all of

136 these reasons, studies of terrestrial ophiolite-hosted alkaline springs and their associated

137 biota and secondary minerals are particularly timely. 


\section{$139 \quad 1.2$ Del Puerto Ophiolite, California Coast Range}

141 Our field area is located within the Del Puerto Ophiolite, approximately $100 \mathrm{~km}$ SE of

142 San Francisco. The ophiolite is part of the California Coast Range and is Jurassic in age

143 (Evarts et al., 1992; Shervais et al., 2005b). The area is marked by rugged, sparsely 144 vegetated terrain, and outcrops exhibit extensive hydrothermal alteration (Evarts and 145 Schiffman, 1983). The ophiolite has been mapped as three distinct rock units: a basal 146 alpine peridotite member, a middle plutonic member, and an upper volcanic member 147 (Evarts, 1977). The study area and surrounding drainage system is hosted within the 148 peridotite body. Del Puerto Creek, the principal drainage for this region, flows eastward 149 toward the San Joaquin Valley. Adobe Springs are low-flow-rate features that discharge 150 into Adobe Creek, a tributary of Del Puerto Creek. The water in the creeks is a mixture 151 of seasonal surface run-off and local spring water.

153 Previously, two distinct alkaline water compositions were identified at the Adobe Spring 154 site: a high-pH ( 12) Ca-OH water interpreted by Barnes et al. (1967) as evidence of 155 active serpentinization, and an alkaline $(\mathrm{pH} \sim 9) \mathrm{Mg}-\mathrm{OH}$ water interpreted to be a mixture 156 of ultramafic-derived and meteoric waters (Barnes and O'Neil, 1971). Barnes and O'Neil 157 (1971), O'Neil and Barnes (1971), and Blake and Peacor (1985) noted the presence of 158 calcite and dolomite cements in the drainages where these alkaline waters occur. 
160 The high $\mathrm{pH} \mathrm{Ca}-\mathrm{OH}$ springs reported by Barnes et al. (1967) are no longer active at the

161 Adobe Springs site. However, the Mg-OH waters, which emanate from Adobe Springs

162 and are also present in the Del Puerto Creek and Adobe Creek drainages, appear to be the

163 source of the carbonate cements that line the drainages. A well drilled into the hillside

164 adjacent to Adobe Springs also produces moderately alkaline $\mathrm{Mg}-\mathrm{OH}$ water, which is

165 bottled and sold for its reputed medicinal benefits (www.mgwater.com).

167 Initial research at this site has focused on characterizing and understanding the micron-

168 scale mineral, morphological and/or stable isotopic biosignatures in carbonate cements

169 associated with ophiolite-hosted alkaline springs. Detection of diagnostic biosignatures

170 would serve to suggest technologies or methodologies most useful for identifying past or

171 presently habitable zones on Mars during flight or sample-return missions. In addition,

172 characterization of the link between precipitating carbonate cements and microbial

173 activity within an ophiolitic terrain increases our understanding of the phylogeny and

174 physiology of microorganisms, including extremophiles, whose characteristics may

175 reflect the nature of primitive environments.

\section{2. Methods}

179 Water, rock, and microbial samples were collected in 2006 and 2007 from the drainage 180 area within a few hundred meters of Adobe Springs, near the confluence of Del Puerto

181 and Adobe Creeks (Figure 1). Water samples were periodically collected at three sample

182 sites near the confluence of the Del Puerto and Adobe Creeks: (1) Del Puerto Creek (the 
183 main drainage within the Del Puerto Ophiolite), (2) Adobe Creek (a tributary of Del

184 Puerto Creek), which has intermittent flow, and (3) Adobe Springs well water (Figure 1).

185 Field measurements of $\mathrm{pH}$ and water temperature were recorded. Water samples were

186 filtered using a 0.45 micron filter and were kept cold prior to analysis. Water chemistry

187 analyses were performed by BC Laboratories (Bakersfield CA). Oxygen and hydrogen

188 isotopic analyses were conducted by the UC Berkeley Laboratory for Environmental and

189 Sedimentary Geochemistry. SOLVEQ (Reed, 1982), a computer program developed to

190 compute aqueous-mineral-gas equilibria, was used to determine mineral saturation

191 indices using measured $\mathrm{Mg}-\mathrm{OH}$ water compositions.

192

193 Carbonate samples were collected at the two creek sites (Figures 1 and 2) for 194 petrographic and chemical analysis. Petrographic characterization of the cements was 195 conducted at Lawrence Berkeley National Laboratory. Selected carbonate samples were 196 analyzed for major and trace elements using an electron microprobe (EMP) at 197 NASA/Johnston Space Center. SEM images were collected at NASA/Ames and

198 NASA/JSC. Analysis of O-isotope variations in the cements on a microscopic scale was 199 conducted using a Secondary Ion Mass Spectrometry (SIMS) CAMECA ims-1280 200 instrument at the University of Wisconsin (Kita et al., 2007; Page et al., 2007; Blank et 201 al., 2007; Bowman et al., 2008). Instrumental bias of SIMS analysis is corrected by the 202 measurements of calcite and dolomite isotope standards and the spot to spot precision of 203 these in situ analyses is typically $0.3 \%$. $(2 \sigma)$.

204

205 A variety of water samples (well water, Adobe and Del Puerto Creek waters) and 206 microbial mat and sediment samples were collected for biologic characterization. 
207 Genomic DNA was extracted from water samples using a commercial DNA extraction

208 procedure (Mo Bio Laboratories, Carlsbad, CA) after an initial filtration of the water

209 through a 0.2 micron filter. DNA was extracted from microbial mat and sediment

210 samples using a modified bead-beating method developed and tested in our laboratory

211 (Green et al., 2008). Samples were PCR-amplified with a variety of primer sets targeted

212 to ribosomal RNA (rRNA) genes of bacteria and Archaea, as well as functional genes for

213 sulfate-reducing prokaryotes (dissimilatory sulfite reductase, dsrAB) (Muyzer et al.,

214 1993; Muzyer and Smalla, 1998; Casamayor et al., 2002; Geets et al., 2006) and

215 methanogens (Methyl Coenzyme M Reductase A, mcrA) (Luton et al. 2002). Bacterial

216 and cyanobacterial primer sets (Muzyer et al., 1993; Muzyer and Smalla, 1998; Nubel et

217 al., 1997) were utilized for rapid community structure analysis using denaturing gradient

218 gel electrophoresis (DGGE).

$220 \quad$ 3. Results

221

222 Water chemistry

223

224 As noted earlier, the highly alkaline $(\mathrm{pH} \sim 12) \mathrm{Ca}-\mathrm{OH}$ springs described by Barnes et al.

225 (1967) are no longer active, so sampling was confined to the $\mathrm{Mg}-\mathrm{OH}$ alkaline waters

226 found in the well, springs, and creeks near Adobe Springs. During the dry summer

227 months, the only flows in this region are those fed by springs, and surface flow is

228 intermittent. Geochemical results of analyses of water samples collected from the Adobe

229 Creek well and Del Puerto Creek are presented in Table 1. Calculated $\log (\mathrm{Q} / \mathrm{K})$ values

230 for disordered dolomite (1.76 and 2.30) and calcite (0.27 and 0.61) for the Adobe Creek 
231 well water and Del Puerto Creek water, respectively, are positive, indicating that the Mg-

$232 \mathrm{OH}$ waters are supersaturated with respect to these carbonate phases. However, previous

233 studies have noted that precipitation of dolomite under ambient conditions is inhibited by

234 kinetic factors (e.g., Land, 1998).

235

$236 \quad$ Carbonate Cements

237

238 Carbonate cements line the creek beds, producing a conglomerate with clasts of

239 carbonate and fragments of eroded peridotite that range from sub-millimeter to tens-of-

$240 \mathrm{~cm}$ in size. Initial investigations of the carbonate cements (Blank et al., 2006) have

241 revealed at least three distinct cement textures: laminated cements, massive or hummocky

242 cements, and dentate calcite crystals lining open pore space. Electron microprobe

243 analysis (Figure 3) indicates that the carbonates range in composition from dolomite to

244 calcite.

246 We detected $\delta^{18} \mathrm{O}$ compositions for laminated carbonate ranging from 19.8-25.4 \%ovsmow

247 over a $\sim 500 \mu \mathrm{m}$ transect perpendicular to a serpentinite fragment grain boundary (Figure

248 4). For these samples, $\delta^{18} \mathrm{O}$ values generally increase with increasing $\mathrm{Mg}$ content in the

249 carbonates, consistent with the observation by Tarutani et al (1969) that magnesian

250 calcites have a larger isotope fractionation relative to water than pure calcite. The range

251 in isotopic composition is consistent with compositions $\left(\delta^{18} \mathrm{O}=23.9-25.2 \%\right.$ ) for 3 bulk

252 Ca-Mg carbonate samples from Del Puerto Creek reported by Barnes and O'Neil (1971).

253 These bulk samples also exhibited a similar positive correlation between $\mathrm{Mg}$ content and 
254 oxygen isotopic composition. We also observed variations in $\delta^{18} \mathrm{O}$ values along-strike

255 within individual bands, with a variation of $1.2 \%$ encountered within a single $\sim 50 \mu \mathrm{m}$ -

256 thick dolomite band. This within band variability is significantly larger than analytical

257 uncertainty and attests to the heterogeneous environment of carbonate deposition. Using

258 the measured oxygen isotopic compositions and temperatures of the sampled waters and

259 dolomite-water and calcite-water oxygen isotope fractionation curves for both abiotic and

260 biotic systems (Tarutani et al., 1969; Schmidt et al., 2005; Vasconcelos et al., 2005;

261 O'Neil et al., 1969; Horita and Clayton, 2007), dolomite $\delta^{18} \mathrm{O}$ values ranging from 24.3

262 to $26.6 \%$ and calcite $\delta^{18} \mathrm{O}$ values ranging from 21.3 to $22.3 \%$ were calculated (Table 2).

263 The dolomite $\delta^{18} \mathrm{O}$ values determined using the microbially mediated fractionation factor

264 of Vasconcelos et al. (2005) are 0.4 to $1.8 \%$ lower than those calculated using the

265 abiogenic fractionation factors of Tarutani et al. (1969) and Schmidt et al. (2005). There

266 is close agreement between the calcite isotopic compositions calculated using O'Neil et

267 al. (1969) (as modified in Friedman and O’Neil, 1977) and Horita and Clayton (2007). In

268 general, the dolomite $\delta^{18} \mathrm{O}$ values calculated using the Vasconcelos fractionation equation

269 more closely match the measured $\delta^{18} \mathrm{O}$ values obtained for the dolomitic portions of the

270 laminated carbonates, suggesting that dolomite precipitation at Adobe Springs was

271 microbially mediated.

272

273 Microbial Communities

274

275 A small-scale analysis of the microbiology of ophiolite-hosted waters was conducted

276 during the summers of 2006 and 2007. All water samples had a $\mathrm{pH}$ of approximately 9, as 
277 did the water overlying the microbial mats. At the Adobe Springs field site, there are a

278 variety of different photosynthetically driven microbial communities, ranging from

279 laminated microbial mats to amorphous algal conglomerates, or periphyton (Figure 2).

280 Because of the ephemeral, and presumably seasonal, presence of these photosynthetic

281 communities, we have not yet ascertained their relationship to the deposition of the Ca-

$282 \mathrm{Mg}$ carbonate cements. However, the presence of laminated microbial mats in this

283 alkaline environment is a peculiar phenomenon that merits further investigation.

285 A clone library of approximately 150 16S rRNA gene sequences was generated from

286 three distinct microbial mat layers as well as water overlying the mat, from nearby water

287 wells, and from Del Puerto Creek water. The microbial mat clone library, composed of

28875 sequences, reveals a diverse microbial community dominated by Cyanobacteria

289 (40\%), Proteobacteria (27\%), Bacteroidetes (13\%) and Firmicutes (11\%). Most of the

290 cyanobacterial sequences belong to two novel lineages of cyanobacteria, a finding

291 confirmed by the recovery of near full length rRNA gene sequences (Genbank accession

292 numbers EU255702-EU255722; www.ncbi.nih.gov). These cyanobacterial sequences

293 belong to the order Oscillatoriales (filamentous, nonheterocystous cyanobacteria) and are

294 most similar to cyanobacterial sequences detected other in freshwater or brackish

295 microbial mats.

297 The most abundant bacterial phylum detected in the clone library generated from the

298 water samples is the phylum Bacteroidetes. In the Del Puerto Creek water, the microbial

299 community is dominated by a single species of Bacteroidetes (13 sequences of 29 total) 
300 most closely related to the organism Chimaereicella alkaliphila, a species isolated from a

301 highly alkaline (pH 11.4) groundwater environment (Tiago et al., 2006). We have also

302 detected the presence of Archaea (including methanogens) and sulfate-reducing

303 prokaryotes in the mats and from well water from Adobe Springs by PCR with rRNA

304 gene and $d s r A B$ gene primer sets, though these organisms have not yet been identified via

305 sequence analysis. Many of the methanogens, detected with archaeal 16S rRNA gene

306 primers and with mcrA gene primers, are closely related to the Methanobacterium

307 alcaliphilum strain DSM3387, an alkaliphilic hydrogen-consuming $\left(\mathrm{H}_{2} / \mathrm{CO}_{2}\right)$ methanogen

308 from a deep coal seam groundwater sample with a pH of $\sim 8.4$ (吕649335). The putative

309 identification of alkaliphilic organisms in the Del Puerto Creek and cultivation analyses

310 of cyanobacteria from the microbial mats suggest that the elevated $\mathrm{pH}$ in this

311 environment most likely exerts a selective influence on the composition of the microbial

312 communities.

313

314 4. Discussion

316 There is an extensive literature demonstrating that the presence and activity of microbial

317 populations are critical to the precipitation of carbonates, particularly magnesium-rich

318 carbonates, such as dolomite (e.g., Vasconcelos et al., 1995; Wright, 1999; Warthmann et

319 al., 2000; Barton et al., 2001; van Lith et al., 2003; Roberts et al., 2004; Altermann et al.,

320 2006). Microbial involvement in carbonate precipitation has been demonstrated for

321 stratified, laminated structures such as stromatolites (Dupraz and Visscher, 2005), and

322 these structures, generally composed of limestone or dolomite, have been found in the 
323 sedimentary record dating back almost 3.5 billion years (Awramik, 1984; Altermann et

324 al. 2006). The best-studied environments for production of stromatolites are marine or

325 hypersaline environments. Although such systems have relatively high concentrations of

326 sulfate, which generally inhibits the precipitation of dolomite (Baker and Kastner, 1981),

327 dolomite or Mg-rich carbonates can be precipitated under appropriate environmental

328 conditions. Microorganisms can provide the conditions required for precipitation of

329 carbonates: elevated $\mathrm{pH}$ (photosynthesis and anaerobic respiration), elevated dissolved

330 inorganic carbon (respiration), and nucleation sites from extracellular polymeric

331 substances (EPS), or degradation of EPS resulting in the release of cations (Dupraz and

332 Visscher, 2005). However, microbial activities may also inhibit the precipitation of

333 carbonates, by cation capture by EPS, consumption of DIC, and acidification (sulfide

334 oxidation) (Barron et al., 2006; Dupraz et al., 2004; Dupraz and Visscher, 2005; Hartley

335 et al., 1996). In marine environments, the key microbial functions involved in the

336 precipitation of carbonates appear to be photosynthesis and anaerobic heterotrophic

337 oxidation of organic matter, generally coupled to sulfate reduction (cf., Visscher et al.,

338 1998; Wright and Altermann, 2000; Visscher et al., 2000; Visscher and Stolz, 2005;

339 Altermann et al., 2006).

340

341 In alkaline, hypersaline lakes in South Australia, the heightened activity of sulfate-

342 reducing bacteria (SRB) during seasonal evaporation events was correlated with the

343 precipitation of dolomite (Wright, 1999). Carbonate deposits can also occur under

344 freshwater conditions, and have been observed in association with alkaline springs

345 emanating from altered ophiolites (Barnes and O'Neil, 1971). While cyanobacterial 
346 activity has been implicated for some freshwater carbonate deposits (e.g. Freytet and

347 Verrecchia, 1998; Merz-Preiss and Riding, 1999), the association of microbial activity

348 with carbonates precipitating in ophiolite environments has not been studied in detail.

349 However, in our initial characterization of the Adobe Creek locality, identified

350 populations of alkaliphilic organisms in the Del Puerto Creek and cyanobacteria from the

351 microbial mats are similar in nature to the types of organisms encountered in stromatolite

352 ecosystems, which are closely linked to biological precipitation of carbonates. The good

353 match between $\delta^{18} \mathrm{O}$ values calculated using the microbially mediated isotopic

354 fractionation equation of Vasconcelos (2005) and measured $\delta^{18} \mathrm{O}$ values from the

355 laminated carbonates supports the idea that precipitation of dolomites at Adobe Springs

356 under ambient temperature conditions $\left(18-24^{\circ} \mathrm{C}\right)$ is facilitated by the presence of the

357 alkaliphilic microbial community.

358

359 5. Conclusions

360

361 The process of serpentinization of mafic and ultramafic rocks produces Mg-rich alkaline

362 waters, which are associated with $\mathrm{Mg}-\mathrm{Ca}$ carbonate cements and unusual microbial

363 communities. The process of serpentinization can generate methane and hydrogen, two

364 potential sources of energy for chemosynthetic organisms. Such a setting (where water is

365 in contact with mafic and ultramafic rocks) may serve as a good analog for similar

366 environments on Mars that may be capable of supporting life. 
368 We have focused our initial investigation on three critical components of the Adobe

369 Springs system: 1) the chemistry of the alkaline waters emanating from mafic and

370 ultramafic rocks; 2) the types and compositions of actively precipitating carbonate

371 cements found lining the adjacent creek drainages, and; 3) the novel microbial

372 communities associated with the alkaline waters and carbonate cements. The deposition

373 of dolomite cements from these low temperature cements may require microbial

374 mediation, which would thus represent a biosignature of this particular biogeochemical

375 environment.

376

377 Additional work is needed to confirm the hypothesis that serpentinite-associated

378 carbonate cements can be a biosignature. One possible approach would be to examine

379 the stable isotope composition of carbon in the cements to ascertain whether they contain

380 a biogenic signature (e.g., García del Cura et al., 2001; Peckman et al., 1999; Cavagna et

381 al., 1999). Laboratory precipitation experiments conducted using sterilized stream fluids

382 with and without microbial cultures selected from those identified in the alkaline waters

383 may also provide information on the possible role that biomineralization may play in the

384 generation of the carbonate cements, in particular, the dolomite. If such a link can be

385 demonstrated, then dolomite precipitation in hydrothermally altered mafic and ultramafic

386 rocks could be used as a biomarker on Mars and other planets.

\section{Acknowledgments}

389 Financial support for our work at Adobe Springs came from the NASA Astrobiology

390 Institute Grant ("Linking Our Origins to Our Future", P.I. David Des Marais, 
391 NASA/Ames Research Center) and a sub-contract to the SETI Institute (Cooperative

392 Agreement NNA06CB35A). Additional financial support came from the NASA

393 Postdoctoral Program, managed by Oak Ridge Associated Universities. Support to P.

394 Dobson at Lawrence Berkeley National Laboratory was provided under Contract No. DE-

395 AC02-05CH11231 with the U.S. Department of Energy. Wisc-SIMS, the Wisconsin

396 SIMS Laboratory, is partially funded by NSF-EAR (0319230, 0509639, 0744079), DOE

397 (93ER14389), and the NASA Astrobiology Institute.

399 This work was a natural outgrowth of a related project conducted by Professor Mitch 400 Schulte (U. Missouri) and Dr. Dave Blake (NASA/Ames) and funded by NASA's

401 Exobiology Program. We thank Dr. Robert Coleman for his suggestion to explore the site 402 at Adobe Springs and for sharing his knowledge of the Del Puerto Ophiolite. We thank

403 Bill Evans and Bob Mariner and other members of the Hydrology Branch of the U.S.

404 Geological Survey, Menlo Park, CA, for discussions concerning California spring 405 chemistry. Bob Mariner shared the field notebook of the late Ivan Barnes, who studied 406 the waters at Adobe Springs extensively in the 1960's. We thank our colleagues Kendra 407 Turk and Mike Kubo (SETI Institute) and Alaina Brinley (National Science Foundation 408 Research Experience for Undergraduates Grant to the SETI Institute, P.I. Cynthia 409 Phillips) for laboratory and field assistance. We appreciate the assistance of Linda L. 410 Jahnke in visual characterization of cyanobacterial isolates from the microbial mats. We 411 also wish to thank Paul Mason (Mgwaters.com) for granting permission to conduct this 412 work on his property and for his enthusiastic support of this project. We thank Gian 
413 Gabriele Ori, Goro Komatsu, and an anonymous reviewer for their constructive reviews

414 of this paper.

415

416 References

418 Altermann, W., Kazmierczak, J., Oren, A., and Wright, D.T., 2006. Cyanobacterial 419 calcification and its rock-building potential during 3.5 billion years of Earth history. 420 Geobiology 4, 147-166.

421 Andrews-Hanna, J.C., Phillips, R.J., and Zuber, M.T., 2007. Meridiani Planum and the 422 global hydrology of Mars. Nature 446, 163-166.

423 Awramik, S.M., 1984. Ancient Stromatolites and Microbial Mats, In: Microbial Mats: 424 Stromatolites. (eds. Y. Cohen, R.W. Castenholz, and H. Halvorson) New York: Alan $425 \quad$ R. Liss, Inc., pp.1-22.

426 Baker, P.A., and Kastner, M., 1981. Constraints on the formation of sedimentary 427 dolomite. Science 213, 214-216.

428 Baker, V.R., 2006. Geomorphological Evidence for Water on Mars. Elements 2, 139$429 \quad 143$.

430 Barnes, I., LaMarche, Jr., V.C., and Himmelberg, G., 1967. Geochemical evidence of 431 present-day serpentinization. Science $156,830-832$.

432 Barnes, I., and O'Neil, J.R., 1971. Calcium-magnesium carbonate solid solutions from 433 Holocene conglomerate cements and travertines in the Coast Range of California. 434 Geochim. Cosmochim. Acta 35, 699-718. 
435 Barron, C., Duarte, C.M., Frankignoulle, M., and Borges, A.V., 2006. Organic carbon 436 metabolism and carbonate dynamics in a Mediterranean seagrass (Posidonia 437 oceanica) meadow. Estuaries and Coasts 29, 417-426.

438 Barton, H.A., Spear, J.R., and Pace, N.R., 2001. Microbial life in the underworld: 439 Biogenicity in secondary mineral formations. Geomicrobiology J. 18, 359-368.

440 Beaty, D.W., Clifford, S.M., Borg, L.E., Catling, D.C., Craddock, R.A., Des Marais, D.J., 441 Farmer, J.D., Frey, H.V., Haberle, R.M., McKay, C.P., Newsom, H.E., Parker, T.J., 442 Segura, T., and Tanaka, K.L., 2005. Key science questions from the Second 443 Conference on Early Mars: Geologic, hydrologic, and climatic evolution and the 444 implications for life. Astrobiology 5, 663-689.

445 Blake, D.F., and Peacor, D.R., 1985. TEM/STEM microanalysis of Holocene fresh-water 446 magnesian carbonate cements from the Coast Range of California. Amer. Mineral. $447 \quad 70,388-394$.

448 Blank, J.G., Blake, D.F., Green, S.J., Brinley, A.I., Jahnke, L.L., Kubo, M.D., Hoehler, 449 T.M., and Des Marais, D.J., 2006. Biogeochemistry of Ca-Mg carbonate cements 450 associated with ophiolite-hosted cold springs, Coast Range, California, USA. Geol. $451 \quad$ Soc. Amer. Abstracts with Programs 38, 505.

452 Blank, J.G., Valley, J.W., Treiman, A.H., Kita, N., and Blake, D.F., 2007. Oxygen 453 isotope variation in $\mathrm{Ca}-\mathrm{Mg}$ carbonate cements in the California Coast Range 454 Ophiolite: Geochemistry of Martian analog environments. Lunar Planet. Sci. Conf. 45538 , Abstract 2150.

456 Boston, P.J., Ivanov, M.V., and Mckay, C.P., 1992. On the possibility of chemosynthetic 457 ecosystems in subsurface habitats on Mars. Icarus 95, 300-308. 
458 Bowman, J.R., Valley, J.W., and Kita, N.T., 2008. Mechanisms of oxygen isotopic 459 exchange and isotopic evolution of ${ }^{18} \mathrm{O} /{ }^{16} \mathrm{O}$-depleted periclase zone marbles in the 460 Alta aureole, Utah-Insights from ion microprobe analysis of calcite. Contrib. Min. $461 \quad$ Pet. (in press).

462 Casamayor, E.O., Massana, R., Benlloch, S., Øvreås, L., Díez, B., Goddard, V.J., Gasol, 463 J.M., Joint, I., Rodríguez-Valera, F., and Pedrós-Alió, C., 2002. Changes in archaeal, 464 bacterial and eukaryal assemblages along a salinity gradient by comparison of genetic 465 fingerprinting methods in a multipond solar saltern. Environ. Microbiol. 4, 338-348.

466 Cavagna, S., Clari, P., and Martire, L., 1999. The role of bacteria in the formation of cold 467 seep carbonates: geological evidence from Monferrato (Tertiary, NW Italy). Sed. 468 Geol. 126, 253-270.

469 Christensen, P.R., McSween, H.Y., Jr., Bandfield, J.L., Ruff, S.W., Rogers, A.D., 470 Hamilton, V.E., Gorelick, N., Wyatt, M.B., Jakosky, B.M., Kieffer, H. H., Malin, 471 M.C., and Moersch, J.E., 2005. Evidence for magmatic evolution and diversity on 472 Mars from infrared observations. Nature 436, 504-509.

473 Dietrich, W.E. and Perron, J.T., 2006. The search for a topographic signature of life. $474 \quad$ Nature 439, 411-419.

475 Dupraz, C., and Visscher, P.T., 2005. Microbial lithification in marine stromatolites and 476 hypersaline mats. Trends in Microbiology 13, 429-438.

477 Dupraz, C., Visscher, P.T., Baumgartner, L.K., and Reid, R.P., 2004. Microbe-mineral 478 interactions: early carbonate precipitation in a hypersaline lake (Eluthera Island, 479 Bahamas). Sedimentology 51, 745-765. 
480 Eiler, J.M., Valley, J.W., Graham, C.M., and Fournelle, J., 2002. Two populations of

481 carbonate in ALH84001: Geochemical evidence for discrimination and genesis.

482 Geochim. Cosmochim. Acta 66, 1285-1303.

483 Evarts, R.C., 1977. The geology and petrology of the Del Puerto Ophiolite, Diablo

484 Range, central California Coast Ranges. In: North American ophiolites (eds. R.G.

485 Coleman and W.P. Irwin). Oregon Dept. Geol. Mineral Ind. Bull. 95, 121-139.

486 Evarts, R.C., and Schiffman, P., 1983. Submarine hydrothermal alteration of the Del

487 Puerto Ophiolite, California. Amer. J. Sci. 283, 289-340.

488 Evarts, R.C., Sharp, W.D., and Phelps, D.W., 1992. The Del Puerto Canyon remnant of

489 the Great Valley Ophiolite: Geochemical and age constraints on its formation and

$490 \quad$ evolution. Amer. Assoc Petrol. Geol. Bull. 76, 418.

491 Fisk, M.R., and Giovannoni, S.J., 1999. Sources of nutrients and energy for a deep

492 biosphere on Mars. J. Geophys. Res. 104, 11805-11816.

493 Formisano, V., Atreya, S., Encrenaz, T., Ignatiev, N., and Giuranna, M., 2004. Detection

494 of methane in the atmosphere of Mars. Science 306, 1758-1761.

495 Freytet, P., and Verrecchia, E.P., 1998. Freshwater organisms that build stromatolites: a 496 synopsis of biocrystallization by prokaryotic and eukaryotic algae. Sedimentology 45 , $497 \quad 535-563$.

498 Friedman, I., and O’Neil, J.R., 1977. Compilation of stable isotope fractionation factors 499 of geochemical interest. USGS Prof. Paper 440-KK.

500 Früh-Green, G.L., Kelley, D.S., Bernasconi, S.M., Karston, J.A., Ludwig, K.A., 501 Butterfield, D.A., Boschi, C., and Proskurowski, G., 2003. 30,000 years of 502 hydrothermal activity at the Lost City Vent Field. Science 301, 495-498. 
503 García del Cura, M.A., Calvo, J.P., Ordóñez, S., Jones, B.F., and Cañaveras, J.C., 2001.

504 Petrographic and geochemical evidence for the formation of primary, bacterially 505 induced lacustrine dolomite: La Roda "white earth" (Pliocene, central Spain). $506 \quad$ Sedimentology 48, 897-915.

507 Geets, J., Borremans, B., Diels, L., Springael, D., Vangronsveld, J., Van der Lelie, D., 508 and Vanbroekhoven, K., 2006. DsrB gene-based DGGE for community and diversity 509 surveys of sulfate-reducing bacteria. J. Microbiol. Methods 66, 194-205.

510 Green, S.J., Blackford, C., Bucki, P., Jahnke, L.L., Bebout, B.M., and Prufert-Bebout, L., 5112008 . A salinity and sulfate manipulation of hypersaline microbial mats reveals stasis 512 in the cyanobacterial community structure. ISME Journal 2, 457-470.

513 Hartley, A.M., House, W.A., Leadbeater, B.S.C., and Callow, M.E., 1996. The use of 514 microelectrodes to study the precipitation of calcite upon algal biofilms. J. Colloid 515 Interface Sci. 183, 498-505.

516 Horita, J., and Clayton, R.N., 2007. Comment on the studies of oxygen isotope 517 fractionation between calcium carbonates and water at low temperatures by Zhou and 518 Zheng $(2003 ; 2005)$. Geochim. Cosmochim. Acta 71, 3131-3135.

519 Kelley, D.S., Karson, J.A., Früh-Green, G.L., Yoerger, D.R., Shank, T.M., Butterfield, 520 D.A., Hayes, J.M., Schrenk, M.O., Olson, E.J., Proskurowski, G., Jakuba, M., 521 Bradley, A., Larson, B., Ludwig, K., Glickson, D., Buckman, K., Bradley, A.S., 522 Brazelton, W.J., Roe, K., Elend, M.J., Delacour, A., Bernasconi, S.M., Lilley, M.D., 523 Baross, J.A., Summons, R.E., and Sylva, S.P., 2005. A Serpentinite-Hosted 524 Ecosystem: The Lost City Hydrothermal Field. Science 307, 1428-1434. 
525 Kita N.T., Ushikubo, T., Fu, B., Spicuzza M.J., and Valley, J.W., 2007. Analytical

526 developments on oxygen three isotope analyses using a new generation ion

527 microprobe IMS-1280. Lunar Planet. Sci. Conf. 38, Abstract 1981.

528 Knoll, A.H., and Grotzinger, J., 2006. Water on Mars and the prospect of Martian life.

$529 \quad$ Elements 2, 169-173.

530 Land, L.S., 1998. Failure to precipitate dolomite at $25^{\circ} \mathrm{C}$ from dilute solution despite

$531 \quad 1000$-fold oversaturation after 32 years. Aquatic Geochem. 4, 361-368.

532 Leshin, L., McKeegan, K., and Harvey, R., 1998. Oxygen isotopic constraints on the

533 genesis of carbonates from Martian meteorite ALH84001. Geochim. Cosmochim.

$534 \quad$ Acta $62,3-13$.

535 Leshin, L.A., and Vicenzi, E., 2006. Aqueous processes recorded by Martian meteorites:

536 Analyzing Martian water on Earth. Elements 2, 157-162.

537 Luton, P.E., Wayne, J.M., Sharp, R.J., and Riley, P.W., 2002. The mcrA gene as an

538 alternative to $16 \mathrm{~S}$ rRNA in the phylogenetic analysis of methanogen populations in $539 \quad$ landfill. Microbiology 148, 3521-3530.

540 McEwen, A.S. , Hansen, C.J., Delamere, W.A., Eliason, E.M., Herkenhoff, K.E., 541 Keszthelyi, L., Gulick, V.C., Kirk, R.L., Mellon, M.T., Grant, J.A., Thomas N., 542 Weitz, C.M. Squyres, S.W., Bridges, N.T., Murchie, S.L., Seelos, F., Seelos, K., 543 Okubo, C.H., Milazzo, M.P., Tornabene, L.L., Jaeger, W.L., Byrne, S., Russell, P.S., 544 Griffes, J.L., Martínez-Alonso, S., Davatzes, A., Chuang, F.C., Thomson, B.J., 545 Fishbaugh, K.E., Dundas C.M., Kolb, K.J., Banks, M.E., and Wray, J.J., 2007. A 546 Closer Look at Water-Related Geologic Activity on Mars. Science 317, 1706-1709. 
547 Merz-Preiss, M., and Riding, R., 1999. Cyanobacterial tufa calcification in two

548 freshwater streams: ambient environment, chemical thresholds and biological

549 processes. Sed. Geol. 126, 103-241.

550 Ming, D.W., Mittlefehldt D.W., Morris, R.V., Golden, D.C., Gellert, R., Yen, A., Clark, $551 \quad$ B.C., Squyres, S.W., Farrand, W.H., Ruff, S.W., Arvidson, R.E., Klingelhöfer, G., 552 McSween, H.Y., Rodionov, D.S., Schröder, C., de Souza Jr., P.A., and Wang, A.. 553 2006, Geochemical and mineralogical indicators for aqueous processes in the 554 Columbia Hills of Gusev crater, Mars. J. Geophys. Res. 111, E02S12, 555 doi:10.1029/2005JE002560

556 Muyzer, G., de Waal, E.C., and Uitterlinden, A.G., 1993. Profiling of complex microbial557 populations by denaturing gradient gel-electrophoresis analysis of polymerase chain 558 reaction-amplified genes-coding for 16S Ribosomal-RNA. Appl. Environ. Microbiol. $55959,695-700$.

560 Muyzer, G., and Smalla, K., 1998. Application of denaturing gradient gel electrophoresis 561 (DGGE) and temperature gradient gel electrophoresis (TGGE) in microbial ecology. 562 Antonie van Leeuwenhoek 73, 127-141.

563 Newsom, H.E., Shearer, C.K., and Treiman, A.H., 2001. Mobile elements determined by 564 SIMS analysis in hydrous alteration materials in the Lafayette Martian meteorite. $565 \quad$ Lunar Planet. Sci. Conf. 32, Abstract 1396.

566 Nubel, U., Garcia-Pichel F., and Muyzer, G., 1997. PCR primers to amplify 16S rRNA 567 genes from cyanobacteria. Appl. Environ. Microbiol. 63, 3327-3332.

568 O'Neil, J.R., Clayton, R.N., and Mayeda, T.K., 1969. Oxygen isotope fractionation in 569 divalent metal carbonates. J. Chem. Phys. 51, 5547-5558. 
570 O'Neil, J.R., and Barnes, I., 1971. $\mathrm{C}^{13}$ and $\mathrm{O}^{18}$ compositions in some fresh-water 571 carbonates associated with ultramafic rocks and serpentinites: western United States. $572 \quad$ Geochim. Cosmochim. Acta 35, 687-697.

573 Page F.Z., Ushikubo, T., Kita, N.T., Riciputi, L.R., and Valley, J.W., 2007. High574 precision oxygen isotope analysis of picogram samples reveals $2 \mu \mathrm{m}$ gradients and 575 slow diffusion in zircon. Amer. Mineral. 92, 1772-1775.

576 Peckman, J., Theil, V., Michaelis, W., Clari, P., Gaillard, C., Martire, L., and Reitner, J., 577 1999. Cold seep deposits of Beauvoisin (Oxfordian; southeastern France) and 578 Marmorito (Miocene; northern Italy): microbially induced authigenic carbonates. Int. 579 J. Earth Sci. 88, 60-75.

580 Pentecost, A., 2005. Travertine. Berlin, Springer-Verlag.

581 Reed, M., 1982. Calculation of multicomponent chemical equilibria and reaction 582 processes in systems involving minerals, gases and an aqueous phase. Geochim. 583 Cosmochim. Acta 46, 513-528.

584 Roberts, J.A., Bennett, P.C., González, L.A., Macpherson, G.L., and Milliken, K.L., 585 2004. Microbial precipitation of dolomite in methanogenic groundwater. Geology 32, $586 \quad 277-280$.

587 Schmidt, M., Xeflide, S., Botz, R., and Mann, S., 2005. Oxygen isotope fractionation 588 during synthesis of $\mathrm{CaMg}$-carbonate and implications for sedimentary dolomite 589 formation. Geochim. Cosmochim. Acta 69, 4665-4674.

590 Schulte, M., Blake, D., Hoehler, T., and McCollom, T., 2006. Serpentinization and its 591 implications for life on the early Earth and Mars. Astrobiology 6, 364-376. 
592

593

594

595

596

597

598

599

600

601

602

603

604

605

606

607

608

609

610

611

612

613

Shervais, J.W., Kolesar, P., and Andreasen, K., 2005a. A field and chemical study of serpentinization - Stonyford, California: Chemical fluxes and mass balance. Int. Geol. Rev. 47, 1-23.

Shervais, J.W., Murchey, B.L., Kimbrough, D.L., Renne, P.R., and Hanan, B., 2005b. Radioisotopic and biostratigraphic age relations in the Coast Range Ophiolite, northern California: Implications for the tectonic evolution of the Western Cordillera. Geol. Soc. Amer. Bull. 117, 633-653.

Singer, R.B., and McSween, H.Y., 1993. The igneous crust of Mars: compositional evidence from remote sensing and the SNC Meteorites, in: Resources of near-Earth Space (J.S. Lewis, M.S. Matthews, and M.L. Guerrieri, eds.), University of Arizona Press, Tucson AZ, pp. 709-736.

Sleep N.H., Meibom, A., Fridriksson, Th., Coleman, R.G., and Bird, D.K., 2004. $\mathrm{H}_{2}$-rich fluids from serpentinization: Geochemical and biotic implications. Proc. Nat. Acad. Sci. 101, 12818-12823.

Squyres, S.W., Arvidson, R.E., Bell, III, J.F., Brückner, J., Cabrol, N.A., Calvin, W., Carr, M.H., Christensen, P.R., Clark, B.C., Crumpler, L., Des Marais, D.J., d'Uston, C., Economou, T., Farmer, J., Farrand, W., Folkner, W., Golombek, M., Gorevan, S., Grant, J.A., Greeley, R., Grotzinger, J., Haskin, L., Herkenhoff, K.E., Hviid, S., Johnson, J., Klingelhöfer, G., Knoll, A.H., Landis, G., Lemmon, M., Li, R., Madsen, M.B., Malin, M.C., McLennan, S.M., McSween, H.Y., Ming, D.W., Moersch, J., Morris, R.V., Parker, T., Rice, Jr., J.W., Richter, L., Rieder, R., Sims, M., Smith, M., Smith, P., Soderblom, L.A., Sullivan, R., Wänke, H., Wdowiak, T., Wolff, M., and 
615 Planum, Mars. Science 306, 1698-1703.

616 Squyres, S.W., Grotzinger, J.P., Arvidson, R.E., Bell, III, J.F., Calvin, W. Christensen, 617 P.R., Clark, B.C., Crisp, J.A., Farrand, W.H., Herkenhoff, K.E., Johnson, J.R., 618 Klingelhöfer, G., Knoll, A.H., McLennan, S.M., McSween, Jr., H.Y., Morris, R.V., 619 Rice, Jr., J.W., Rieder, R., and Soderblom, L.A., 2004b. In situ evidence for an 620 ancient aqueous environment at Meridiani Planum. Mars. Science 306, 1709-1714.

621 Squyres, S.W., Knoll, A.H., Arvidson, R.E., Clark, B.C., Grotzinger, J.P., Jolliff, B.L., 622 McLennan, S.M., Tosca, N., Bell, III, J.F., Calvin, W.M., Farrand, W.H., Glotch, 623 T.D., Golombek, M.P., Herkenhoff, K.E., Johnson, J.R., Klingelhöfer, G., McSween, 624 H.Y., and Yen, A.S., 2006. Two Years at Meridiani Planum: Results from the 625 Opportunity Rover. Science 313, 1403-1407.

626 Squyres, S.W. and Knoll, A.H., 2005. Sedimentary rocks at Meridiani Planum: Origin, 627 diagenesis, and implications for life on Mars. Earth Planet. Sci. Lett. 240, 1-10.

628 Surour, A.A., and Arafa, E.H., 1997. Ophicarbonates: calichified serpentinites from 629 Gebel Mohagara, Wadi Ghadir area, Eastern Desert, Egypt. J. African Earth Sci. 24, $630 \quad 315-324$.

631 Tarutani, T., Clayton, R.N., and Mayeda, T.K., 1969. The effect of polymorphism and 632 magnesium substitution on oxygen isotope fractionation between calcium carbonates 633 and water. Geochim. Cosmochim. Acta 33, 987-996.

634 Tiago, I., Mendes, V., Pires, C., Morais, P.V., and Verissimo, A., 2006. Chimaereicella 635 alkaliphila gen. nov., sp. nov., a Gram-negative alkaliphilic bacterium isolated from a 636 nonsaline alkaline groundwater. Syst. Appl. Microbiol. 29, 100-108. 
637 Treiman A.H., 1998. The history of Allan Hills 84001 revised: Multiple shock events. 638 Meteoritics Planet. Sci. 33, 753-764.

639 Treiman, A.H., and Goodrich, C.A., 2002. Pre-terrestrial aqueous alteration of the 640 Y000593 and Y000749 Nakhlite meteorites. Nat. Inst. Polar Res. Symp. Antarctic $641 \quad$ Meteorites XXVII, 166-167.

642 Treiman A.H. and Romanek, C.S., 1998. Bulk and stable isotopic compositions of 643 carbonate minerals in Martian meteorite Allan Hills 84001: No proof of high 644 formation temperature. Meteoritics Planet. Sci. 33, 737-742.

645 Treiman A.H., Lanzirotti, A., and Xirouchakis, D., 2004. Ancient water on asteroid 4 646 Vesta: Evidence from a quartz veinlet in the Serra de Magé eucrite meteorite. Earth 647 Planet. Sci. Lett. 219, 189-199.

648 Valley, J.W., Eiler, J.M., Graham, C.M., Gibson, E.K., Romanek, C.S., and Stolper, 649 E.M., 1997. Low-temperature carbonate concretions in the Martian meteorite 650 ALH84001: Evidence from stable isotopes and mineralogy. Science 275, 1633-1668.

651 Van Lith, Y., Warthmann, R., Vasconcelos, C., and McKenzie, J.A., 2003. Microbial 652 fossilization in carbonate sediments: a result of the bacterial surface involvement in 653 dolomite precipitation. Sedimentology 50, 237-245.

654 Vasconcelos, C., McKenzie, J.A., Bernasconi, S., Grujic, D., and Tien, A.J., 1995. 655 Microbial mediation as a possible mechanism for natural dolomite formation at low 656 temperatures. Nature 377, 220-222.

657 Vasconcelos, C., McKenzie, J.A., Warthmann, R., and Bernasconi, S.M., 2005. 658 Calibration of the $\delta^{18} \mathrm{O}$ paleothermometer for dolomite precipitated in microbial 659 cultures and natural environments. Geology 33, 317-320. 
660 Visscher, P.T., Reid, R.P., and Bebout, B.M., 2000. Microscale observations of sulfate 661 reduction: correlation of microbial activity with lithified micritic laminae in modern 662 marine stromatolites. Geology 28, 919-922.

663 Visscher, P.T., Reid, R.P., Bebout, B.M., Hoeft, S.E., Macintyre, I.G., and Thompson, 664 Jr., J.A., 1998. Formation of lithified micritic laminae in modern marine stromatolites 665 (Bahamas): The role of sulphur cycling. Amer. Mineral. 83, 1482-1493.

666 Visscher, P.T., and Stolz, J.F., 2005. Microbial mats as bioreactors: populations, 667 processes, and products. Palaeogeog., Palaeoclimatol., Palaeoecol. 219, 87-100.

668 Warthmann, R., van Lith, Y., Vasconcelos, C., McKenzie, J.A., and Karpoff, A.M., 2000.

669 Bacterially induced dolomite precipitation in anoxic culture experiments. Geology 28, $670 \quad 1091-1094$.

671 Wright, D.T., 1999. The role of sulfate-reducing bacteria and cyanobacteria in dolomite 672 formation in distal ephemeral lakes of the Coorong region, South Australia. Sed. $673 \quad$ Geol. 126, 147-157.

674 Wright, D.T., and Altermann, W., 2000. Microfacies development in Late Archaean 675 stromatolites and oolites of the Campbellrand Subgroup, South Africa. In: Carbonate 676 Platform Systems. Components and Interactions (Insalco, E., P.W. Skelton, and T.J. 677 Palmer, eds.). Geol.Soc. London Spec. Pub. 178, 51-70.

678 Wyatt, M.B., and McSween, Jr., H.Y., 2006. The orbital search for altered materials on 679 Mars. Elements 2, 145-150. 
682 Figure 1. Field site showing locations of the three sampling sites (indicated by the push 683 pin icons) associated with alkaline waters in the Del Puerto Ophiolite, CA: DP6, at the 684 Del Puerto Creek, Adobe Springs Well, and AC6, at Adobe Creek, a tributary of Del 685 Puerto Creek. Figure made using GoogleEarth.

687 Figure 2. (A-H) Photographs of carbonate cements and microbial communities from the 688 Adobe Springs sampling sites, April-June 2006. (A) Del Puerto Creek (DPC) and (B) 689 Adobe Creek, June 2006, showing carbonate cements and microbial biomass 690 (periphyton). (C) Hand sample of DPC carbonate cement. (D) DPC, 10 miles 691 downstream of sampling site, parallel to the year-round main creek flow. (E) Thin section 692 of serpentine grain bordered by banded carbonate from DPC. White scale bar indicates 1

$693 \mathrm{~mm}$ (horizontal and vertical). (F) Thin, laminated microbial mat underlain by anaerobic 694 mud (AC6). (G) Leptolyngbya-like and (H) Arthrospira-like cyanobacteria recovered 695 from microbial mat samples. Scale bars indicate $30 \mu \mathrm{m}$.

697 Figure 3. Mole fraction of major cations of carbonate cement from Del Puerto Creek, as 698 determined from electron microprobe analysis.

700 Figure 4. Results of EMP and SIMS analysis of a banded cement from the Del Puerto 701 Creek. (A) Photomicrograph of sample in transmitted light, illustrating fine-scale Mg702 Ca carbonate laminae deposited outward from a serpentinized clast. In-situ oxygen 
703 isotopic measurements were made using a CAMECA ims-1280 SIMS at the University 704 of Wisconsin; transect points (in white) were created by the SIMS beam. The polished 705 sample surface was coated with a thin layer of gold prior to analysis; gold in and 706 adjacent to the analysis pits was sputtered during analysis, leaving gold-free regions 707 wider than their corresponding pits (here, the pits are $\sim 8$ or $\sim 15$ microns diameter) in the 708 sample. Yellow scale bar represents $100 \mu \mathrm{m}$; width of cement section is $\sim 550 \mu \mathrm{m}$. (B)

709 Variation in $\delta^{18} \mathrm{O}$ and $\mathrm{Ca} \#$ (the mole fraction of $\mathrm{Ca} /(\mathrm{Ca}+\mathrm{Mg}$ ) as a function of distance 710 from the serpentine grain boundary. 


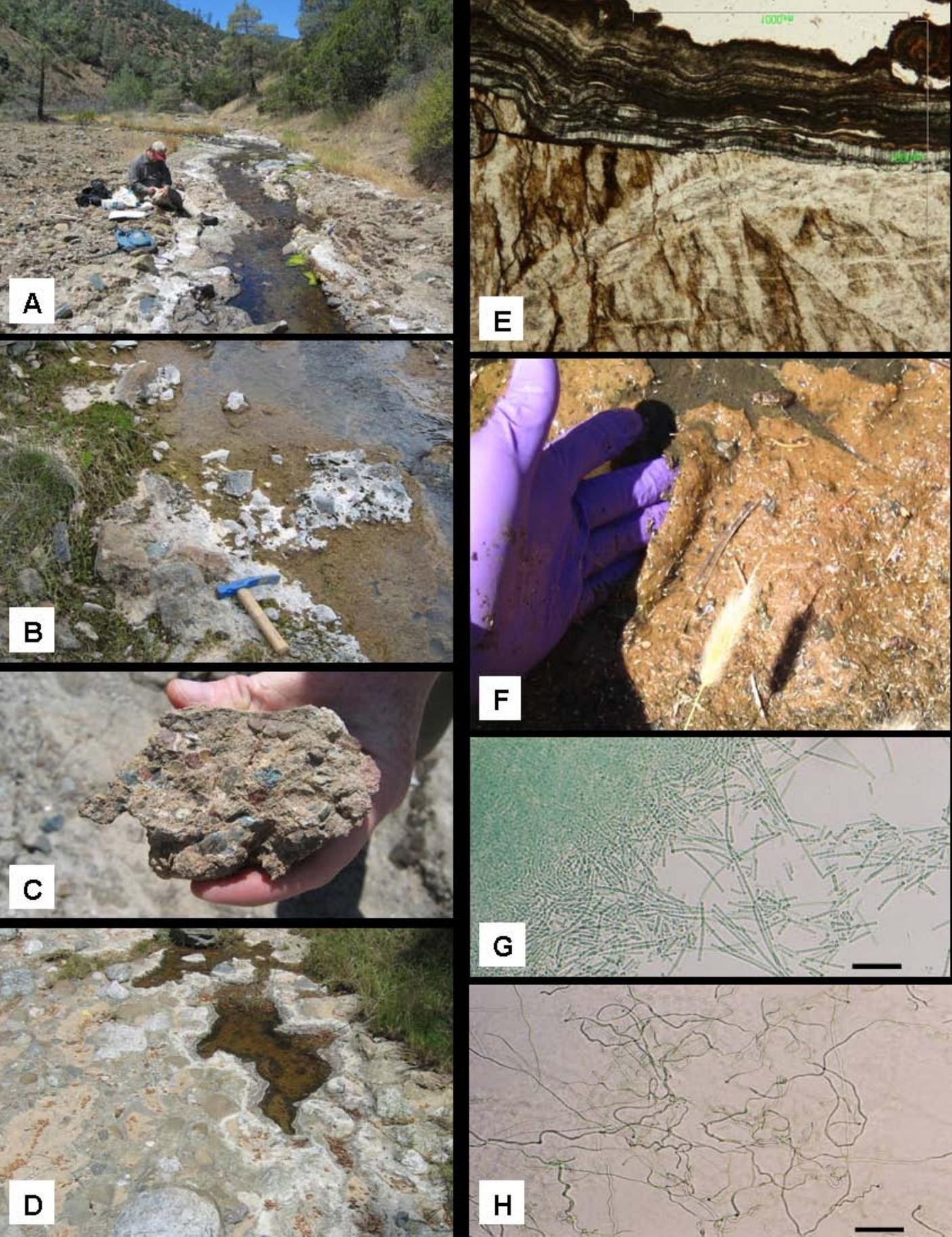


$\mathrm{Ca}$

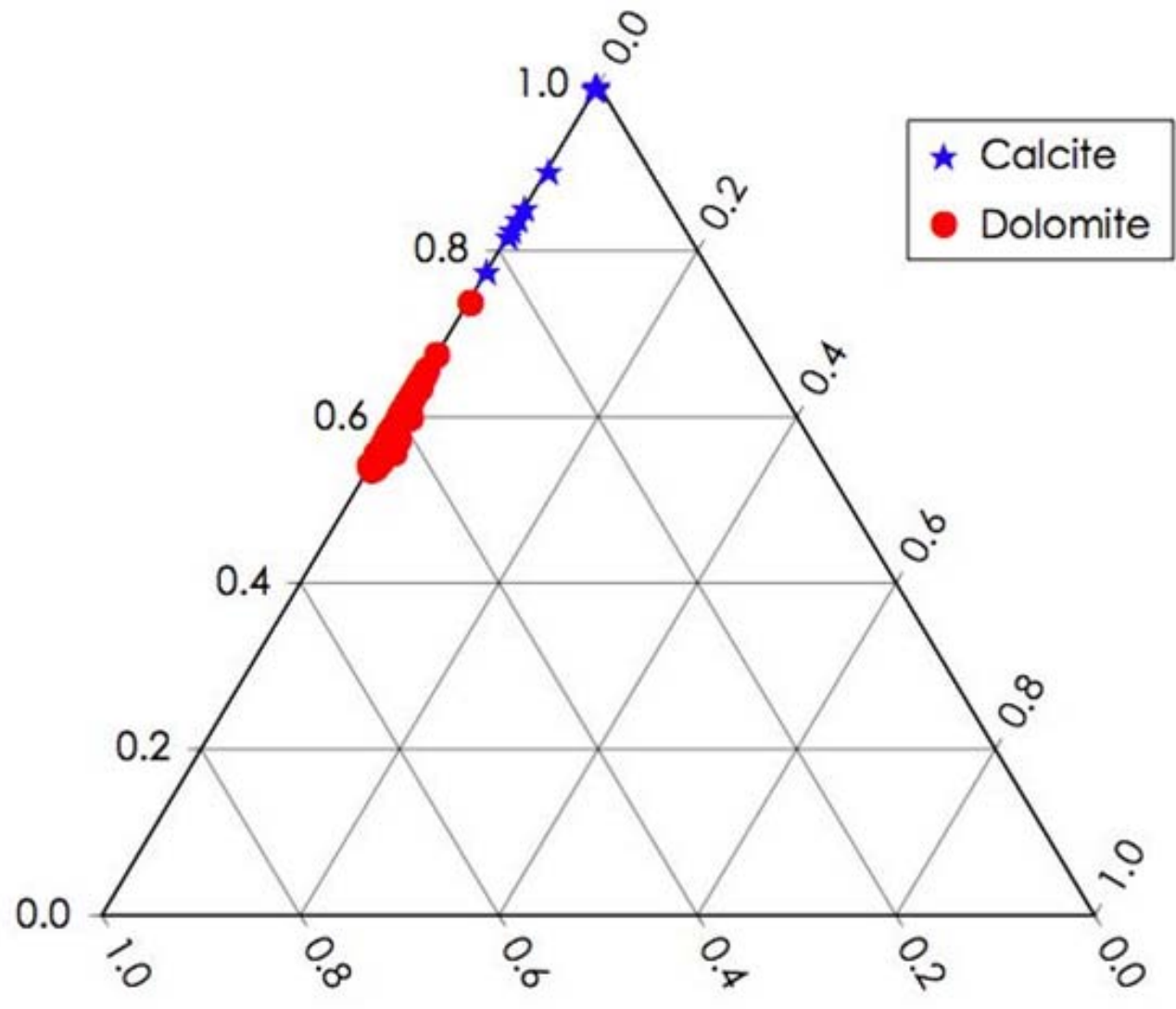



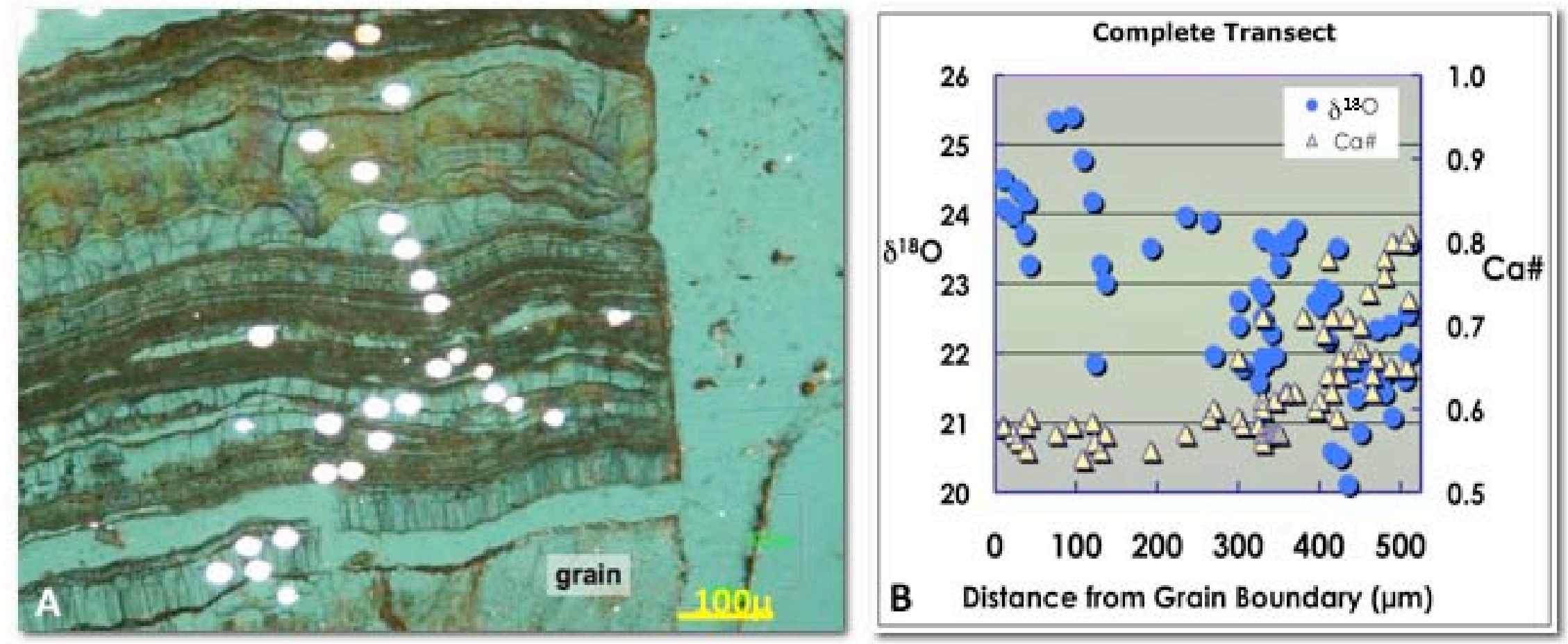
Table 1: Fluid chemistry of representative water samples

\begin{tabular}{|l|l|l|}
\hline & Adobe Springs Well & Del Puerto Creek \\
\hline Collection date & June 9,2007 & June 9, 2007 \\
\hline $\mathrm{Ca}^{2+}$ & 3.5 & 8.1 \\
\hline $\mathrm{Mg}^{2+}$ & 110 & 150 \\
\hline $\mathrm{K}^{+}$ & 0.31 & 0.6 \\
\hline $\mathrm{Na}^{+}$ & 5.4 & 9.6 \\
\hline $\mathrm{HCO}_{3}^{-}$ & 400 & 550 \\
\hline $\mathrm{CO}_{3}{ }^{2-}$ & 66 & 89 \\
\hline $\mathrm{Cl}^{-}$ & 4.8 & 9.5 \\
\hline $\mathrm{NH}_{3}$ (total as $\left.\mathrm{N}\right)$ & 0.01 & 0.018 \\
\hline $\mathrm{SO}_{4}{ }^{2-}$ & 16 & 10 \\
\hline $\mathrm{SiO}_{2}$ & 5.6 & 13 \\
\hline $\mathrm{OH}^{-}$ & $<1.6$ & $<1.6$ \\
\hline $\mathrm{Alkalinity} \mathrm{as} \mathrm{CaCO}$ & 440 & 600 \\
\hline Field pH & 8.73 & 8.52 \\
\hline $\mathrm{Lab} \mathrm{pH}$ & 8.69 & 8.61 \\
\hline $\mathrm{Collection} \mathrm{T}^{\circ} \mathrm{C}$ & 17.8 & 24.2 \\
\hline$\delta{ }^{18} \mathrm{O}$ & -7.9 & -7.1 \\
\hline$\delta \mathrm{D}$ & -57 & -52 \\
\hline
\end{tabular}

Concentrations of dissolved species given in $\mathrm{mg} / \mathrm{L}$; isotopic values reported in permil relative to VSMOW. 
Table 2: Calculated Equilibrium Carbonate Oxygen Isotope Compositions

\begin{tabular}{|l|l|l|}
\hline & Adobe Springs Well & Del Puerto Creek \\
\hline Collection date & June 9, 2007 & June 9, 2007 \\
\hline Collection T ${ }^{\circ} \mathrm{C}$ & 17.8 & 24.2 \\
\hline$\delta^{18} \mathrm{O}_{\text {VSMOW }}$ (per mil) & -7.9 & -7.1 \\
\hline Predicted dolomite compositions (\%o) \\
\hline Tarutani et al. (1969) & 25.3 & 24.7 \\
\hline Schmidt et al. (2005) & 26.6 & 26.1 \\
\hline Vasconcelos et al. (2005) & 24.9 & 24.3 \\
\hline Predicted calcite compositions (\%o) & 21.7 \\
\hline O'Neil et al. (1969) & 22.3 & 21.3 \\
\hline Horita and Clayton (2007) & 21.8 & \\
\hline
\end{tabular}

Fractionation equations used:

$1000 \ln \alpha=2.78 \times 10^{6} \mathrm{~T}^{-2}+0.11$ (Tarutani et al., 1969; corrected in Friedman and O'Neil, 1977 , for the case of $\mathrm{Mg}$ mole fraction $=0.5)$

$1000 \ln \alpha=2.63 \times 10^{6} \mathrm{~T}^{-2}+3.12$ (Schmidt et al., 2005)

$1000 \ln \alpha=2.73 \times 10^{6} \mathrm{~T}^{-2}+0.26$ (Vasconcelos et al., 2005)

$1000 \ln \alpha=2.78 \times 10^{6} \mathrm{~T}^{-2}-2.89$ (O'Neil et al., 1969; corrected in Friedman and O'Neil, 1977)

$1000 \ln \alpha=0.9521 \times 10^{6} \mathrm{~T}^{-2}+11.59 \times 10^{6} \mathrm{~T}^{-1}-21.56$ (Horita and Clayton, 2007) 